\title{
Yeniden İşlevlendirilmiş Anıtsal Yapılarda Deneyim Odaklı Tasarım: Antalya Kaleiçi ve Balbey Örneği
}

\author{
Experience-Oriented Design in Re-Functioned Monumental Spaces: \\ The Example of Kaleiçi Antalya and Balbey
}

\begin{abstract}
Ayşegül DURUKAN *
Öz: Kültürel mirasın bir parçası olan tarihi mekânların orijinal dokusu içinde korunması, yapıların yaşatılması ve gelecek nesillere aktarılması için gereklidir. Korumanın bir bileşeni olarak kabul edilen yeniden işlevlendirme ile yapının sosyal ve kültürel özelliklerinin muhafazası sağlanır. Orijinal planlarına ve tarihi dokusuna sadık kalınarak yeniden işlevlendirilen mimari mekânlar, geleneksel turizmdeki yerleri nedeniyle ülke ekonomisine de katkıda bulunurlar. Geleneksel turizm yapılanması, turistlerin ziyaret etme, görme, öğrenme, eğlenme vb. eylemlerle hayatı farklı şekillerde algılamalarını sağlamak amacıyla deneyim odaklı olarak kurgulanmaktadırlar. Tarihi mekânda paylaşılan bu deneyim, kullanıcı ve mekân arasında bir etkileşime neden olur. $\mathrm{Bu}$ çalışmanın amacı, yeniden işlevlendirilmiş tarihi mekânlarda duyulara dayalı olarak gerçekleşen deneyimin, fiziksel mekân ve mekânsal kimlik algılarına etkisini araştırmaktır. Bunun yanında deneyimin mekânsal hafızaya etki düzeyi de ampirik yaklaşımla tespit edilmeye çalışılacaktır. Çalışmanın ilk bölümünde betimsel tarama modeli kullanılmıştır. Bu bölüm, fiziksel mekân deneyiminin tespit edilmesi için seçilen örnek yapıların, geliştirilen kullanım sonrası değerlendirme anket aracı ile belirlenen örneklem dahilindeki kullanıcılar tarafından değerlendirilmesiyle tamamlanmıştır. İkinci bölümde ise kullanıcılardan, mekânsal kimlik algısının tespiti için deneyimlerini anlatmaları istenmiştir. Sonuçta tarihi mekânlarda deneyim odaklı tasarımın sosyal ve kültürel mirasın aktarımı ve mekânsal kimlik bakımından etkili olduğu sonucuna ulaşılmıştır.
\end{abstract}

\begin{abstract}
Anahtar sözcükler: İç Mekân, Yeniden İşlevlendirme, Tarihi Mekân, Deneyim Odaklı Tasarım
Abstract: It is designed in the original texture of historical sites that are a part of cultural heritage, it is necessary for the survival of the buildings and their transfer to future generations. Structure with refunctioning, which is considered a component of protection. Architectural spaces, which have been refunctioned by sticking to their original plans and historical texture, are also present in the country's economy due to places in traditional tourism. Traditional tourism structuring, tourists visiting, seeing, learning, entertainment etc. It enables them to perceive life in different ways with actions. This effective experience in historical space causes an interaction between the user and the space. The aim of this study is to investigate the experience based on the senses in the re-functional historical spaces according to the perceptions of physical space and spatial identity. It will be tried to be determined with empirical approach. The first view of the study is to examine the descriptive scanning model. See this section for the determination of physical location experience. On the second page, the users were asked to explain the experiences for their detection. As a result, it has come to the conclusion why experience-oriented design in historical places is effective in the transfer of social and focused heritage and spatial identity.
\end{abstract}

Keywords: Interior Space, Re-functionalization, Historical Space, Experience-Oriented Design

Tarihi değer taşıyan mimari yapılar; bulunduğu yörenin kültürünü malzeme ve tasarımıyla somutlaştırarak duyularla algılanabilen hale getiren kültürel kaynaklarıdır. Anıtsal değeri olan bu mekânlar; hacimsel varlıkları, tasarımları, malzemeleri, kullanım amaçları, sundukları hizmetler ve yaşattıkları deneyim ile kullanıcılarını, tarihin bir dönemine götürebilmektedirler.

\footnotetext{
* Dr. Öğr. Ü., Akdeniz Üniversitesi, Mimarlık Fakültesi, İç Mimarlık Bölümü, Antalya, aysegul.drukan@gmail.com.tr, https://orcid.org/0000-0002-0888-5531
} 
Tarihi yapıların bu güçlü özelliklerinin yaşatılabilmesi için yapının, orijinal dokusu içinde korunması ve ilk işlevine paralel olarak yeniden işlevlendirilmesi gerekmektedir.

Küresel ölçekte değerli olan geleneksel yapılar, korunması gereken kültürel mirasın ayrıcalıklı yapılarıdır (Akın et al. 2016, 360). Geleneksel yapılardan biri olan ve anıtsal değer taşıyan mimari yapılar; sahip oldukları yapı teknikleri, malzemeleri, kullanım amaçları, tasarımsal özellikleriyle bulundukları bölgenin kültürünü güçlü şsekilde yansıtan değerlerdir. $\mathrm{Bu}$ değerlerin korunmasını sağlayan önemli etkenlerden biri ise yapının kullanıma devam etmesinin sağlanmasıdır. Bu bağlamda tarihi ve kültürel varlıklar olan mimari yapıların korunmasının, gelecek nesillere doğru aktarılabilmesinin en etkin yolu, bu yapıların 'yaşayan birer varlık' olarak korunarak, yeniden kullanımlarının gerçekleştirilmesidir (Gönül 2016, 82). Bu yöntemle anıtsal yapıların, yaşayan üç boyutlu birer kaynak olarak sosyo-kültürel anlamda tarihsel sürekliliği sağlanabilmektedir.

Toplumların geçmişteki sosyal, ekonomik niteliklerini, kültürel değerlerini yansıtan ve anıtsal değer taşıyan yapıları koruma kavramı; bir bakıma geçmişin anlaşılması ve yaşatılmasını da sağlamaktadır. Korumanın bir bileşeni olarak ele alınan yeniden işlevlendirme sürecinde, sosyal ve kültürel kimliğin korunması bu nedenle büyük önem teşkil etmektedir. Oysaki geleneksel yapıların onarılan ve yeniden işlevlendirilen örnekleri incelendiğinde toplumun değişen kültürel yapısı ve ekonomik beklentilerinden dolayı, koruma bilincinden çok, ticari kaygıların ön plana çıktı̆̆ gözlenmektedir.

Orijinal planlarına ve tarihi dokusuna sadık kalınarak yeniden işlevlendirilmiş mimari mekânlar, varlıkları ile bulundukları yöreye kültürel ve ekonomik katkı sağlamaktadırlar. Bu şekilde yapılanmış mekânlar, kültürel anlamda, dönemin yapı ve tasarım anlayışını gözler önüne serdikleri için kullanıcılar tarafından ziyaret edilerek incelenmektedirler. Böylece taşınmaz kültür varlığı ve kullanıcılar arasında bilgi akışı ve paylaşımı dinamik bir şekilde sağlanabilmektedir. Geleneksel turizm yapılanması turistlerin ziyaret etme, görme, öğrenme, eğlenme ve hayatın farklı şekillerde algılamalarını sağlamak üzerine kurgulanmaktadır (Zoğal \& Emekli 2017, 31).

MÖ V. yüzyılda yaşayan Abderalı Protagoras, insanı her şeyin ölçüsü olarak tanımlamıştır (Burnyeat 1976, 172). Bu bakış açısına yönelik metotların kullanılmasının fark yaratacağı düşünülmektedir. Aynı nedenden dolayı tarihi değeri olan yeniden işlevlendirilmiş mekânların insan için korunarak, ona optimal derecede hizmet etmesinin sağlanması amaçlanmaktadır. Bu nedenle anıtsal değeri olan mimari yapıların kültüre ve insana kattıkları tüm pozitif katkıların yanında kullanıcılara gerçekleştirdikleri ziyaret sırasında kendilerini özel hissetmelerini sağlayacak bir modelin sorgulanması, buna bağlı olarak kullanıcıların mekânla interaktif bir ilişki içine girmelerini sağlayan bir model geliştirilmesi araştırmanın konusunu oluşturmuştur.

Çalışmanın amacı, yeniden işlevlendirilmiş tarihi mekânlarda duyulara dayalı olarak gerçekleşen deneyimin, fiziksel mekân ve mekânsal kimlik algılarına etkisini araştırmaktır. Bu amaç doğrultusunda araştırmanın hipotezi; 'tarihi yapıların yaşatılmasında deneyim odaklı tasarımın kullanılması yapıya olan ilgiyi arttıracağı için kullanıcıların fiziksel mekân algılarını da olumlu yönde etkiler' olarak belirlenmiştir. Bu çalışmada deneyimsel modül çerçevesinde yeniden işlevlendirilmiş mekânların tasarımları ve buna paralel ortaya çıkan faydalar incelenmektedir. Modelin yapılandırılması sırasında mekânın niteliği ve bireye sunduklarının içerik odak noktası haline gelmektedir.

Araştırma kapsamında, tarihi değer açısından Antalya Kaleiçi ve Balbey bölgesinde yer alan anıt yap1 özelliği taşıyan ve yeniden işlevlendirilmiş tarihi yapılar incelenmiştir. Araştırmanın yapıldığ 1 tarihte, Antalya Kaleiçi ve Balbey'de bulunan 75 adet anıt yapı incelenmiş, bunların arasından 4 yapı araştırmaya dâhil edilmiştir. Bölgede bulunan cami, türbe gibi yapılar ilk 
işlevlerini korudukları için kapsam dışında bırakılırken, kiliseler ilk işlevlerini koruyamadıkları için kapsama dâhil edilmişlerdir. Araştırmada seçilen yapıların gözlemsel analizlerini yapmak için geliştirilen kullanım sonrası değerlendirme anketi, Kaleiçi ve Balbey bölgesindeki yapıları deneyimlemiş olan bir örneklem grubuna çevrimiçi olarak uygulanmıştır. Elde edilen veriler excel programı yardımıyla düzenlenerek yüzdelikler belirlenmiştir. Bu çalışmada Antalya Büyükşsehir Belediyesi KUDEB (Koruma Uygulama ve Denetim Bürosu) arşivinde yer alan dokümanlardan, haritalardan, planlardan ve fotoğraflardan faydalanılmıştır.

\section{Genel Tanım ve Kavramlar}

Kullanıcıların deneyimsel aktivitelerden sonra edindiği anıların, hafızada iz bıraktı̆̆ı, araştırmalar doğrultusunda ispatlanmıştır. Deneyimsel aktiviteler için yapılan harcamaların, maddi harcamalardan daha mutluluk verici bir dinamik içerdiği gerçeği de ortaya konmuştur (Van Boven \& Gilovich 2003, 1193). Deneyimsel aktivitelerin; bireyler üzerindeki pozitif izdüşümlerinin nedeni, deneyimlerin insan bilincinde yarattığı etkilerden kaynaklanmaktadır. Yaşanılan deneyimler aracılığı ile nesnel objeler, mekânlar insan belleğinde kalıcı hale gelerek hatıralara dönüşebilmektedir (Dewey 2012, 6). Deneyim olgusu aracılığıyla kurgu ve gerçeklik insan belleğinde bir araya gelebilmektedir (Eroğlu 2011, 34). Bu şekilde bireyin imgeleminde gelişme ve tatmin duyguları oluşmaktadır. Deneyim kavramının bireylere kazandırdığı pozitif ivmelenmelerin teşhisi ile birlikte ekonomi ve pazarlama alanında kullanılmaya başlanmıştır. $\mathrm{Bu}$ şekilde meta, mal, hizmetten sonra dördüncü bir ekonomik sunu türü ve aralarından en çok akılda kalıcı olandır (Pine \& Gilmore 1999, 5).

Mekânın içeriği, kullanıcısı tarafından okunabilir. Tarihi binalarda ise içerik, kendiliğinden zengin ve ilgi çekici bir şekilde kullanıcının hafızasında yer alabilmektedir. Deneyimsel alanların yapının işlevine göre yapılandırıldığı mekânlar akılda kalıcı olmaktadırlar. Mekân, kullanıcılarının isteklerine hitap etmek ve onlara aradıkları servisi, mekân tasarımı aracılığıyla sunmak stratejik yapılanma ile mümkün olabilmektedir. Bireyin belirli bir mekân ile bağ kurması için o mekânın, bireyin sosyalleşmesine ve kendisini gerçekleştirmesine izin vermesi gerekmektedir. Ziyaretçiler için özel olarak tasarlanmıș deneyimlerin, mekân içinde bir tiyatro sahnesi gibi kurgulanması ve kullanıma sunulması bu durumun gerçekleşmesini sağlamaktadır. Elde edilen psikolojik verilerin güçlü etki alanından yola çıkılarak deneyimsel modül geliştirilmiştir. Deneyim tasarımında kişilere en üst düzeyde hitap edebilmek için 'Stratejik Deneyimsel Modül' kullanılmaktadır. Bu modül algılamak, hissetmek, düşünmek, faaliyette bulunmak ve ilişkilendirmek olarak belirtilen bu beş ayrı deneyim tasarımının bir arada kullanılmasıyla bütünlenmektedir (Schmitt 1999, 60). Bu metot ile mekân tasarımının yapılandırılmasıyla oluşan insan odaklı yaklaşım, insan ve mekân arasında bă̆ kurulmasını kolaylaştırmaktadır.

Bireylerde algı beş duyu aracılığı ile gerçekleşirken, duygular; algı, hisler, düşünceler, faaliyetler ve ilişkilendirmeler aracılığıyla oluşmaktadır. Bireylere en üst düzeyde hitap edilmesinin beğeni ve istek uyandırdığı göz önünde tutulursa stratejik deneyimsel modüle göre tasarlanan mekânların beğenilen ve istek uyandıran yapılar olacağı görülmektedir. Deneyimsel modüle göre yeniden işlevlendirilmiş anıtsal değeri olan binaların cazibe merkezi haline gelmesi mümkün olmaktadır. Mekân tasarımının tarihi duyarlılıkta yapılandırılması ve orijinal fonksiyonu ile yeni fonksiyonu arasında bağ kurulması ilgi çeken bir bütünlüğün oluşmasını sağlayan en önemli etkenlerdendir. Tasarım öncesi mekânın orijinal tarihi, işlevi ve yeni işlevi üzerine araştırma yapılması ve bu üç etkeninin aynı konsept içinde değerlendirilmesi ile mekân içinde kavramsal bütünlük sağlanmaktadır.

Anıtsal değer taşıyan mekânların yeniden işlevlendirilmesinde, deneyimsel modülün kullanılması; tarihi verilerin korunmasını ve mekândan ekonomik olarak üst düzeyde fayda sağlamaktadır. Stratejik deneyimsel modülün bütünsel olarak yeniden işlevlendirme sürecine 
adapte edilmesiyle bu amaç optimal düzeyde gerçekleştirilmektedir. Bu bağlamda yeniden işlevlendirilmiş mekân içinde ziyaretçinin keşfine sunulan deneyim; tarihi döneme uygunluk ve birey beklentilerini karşılar şekilde tasarlanmaktadır. Mekân içinde sunulan deneyimin tarihsel gerçekliği yansıtması ve mekânı ziyaret eden kişilerin beklentilerine cevap vermesi gerekmektedir. Yeniden işlevlendirilmiş yapı içinde tasarlanan deneyimin mekânın tarihini, fonksiyonel ve duygusal yönlerini birleştirerek ziyaretçi izlenimine sunması esastır.

Anıtsal yapıların tekrar işlevlendirilmesinde deneyim kavramının istek ve merak uyandıran bir anahtar niteliğinde olduğu görülmektedir. Bahse konu duyarlılıkların en başarılı şekilde gerçekleştirilebilmesi için dinamik deneyimlerin ziyaretçilere verilmesi önemlidir. Bu koşulu sağlayabilmek için mekânın kimlere hitap ettiği belirlenmektedir. Hedef kitle olarak adlandırılan bu kesim, anıtsal tarihi mekâna ilgi duyabilecek gruplardır. Deneyimsel ve mekânsal tasarımların tüm aşamalarının hedef kitleye göre yapılandırılması ise en temel adımdır. Çünkü mekân birey için ne kadar çok anlam içeriyorsa, o kadar akılda kalıcı olmaktadır (Öymen Özak \& Pulat Gökmen 2009, 150). Bu grup ya da topluluğun isteklerinin ve beklentilerinin anlaşılması ile onlara uygun tasarımlar geliştirilebilmektedir. Bu teşhisin yapılmasından sonra tarihi doku içinde yaşatılmak istenen deneyimler tarih, eski ve yeni fonksiyon uyumlulukları dahilinde geliştirilmektedir. 1980 yılında yeniden işlevlendirilmiş olan Sarnıç Restaurant bu bakış açısına bir örnek olarak gösterilebilir. İstanbul, Soğukçeşme sokağında bulunan yapı, Romalılar tarafından 542 yılında inşa edilmiş bir sarnıçtır. Yapı, altı adet masif taş sütunlar ile taşınmaktadır. Yeniden işlevlendirme sırasında yapının orjinalliğini bozan müdahaleler temizlenmiş ve yapıldığı dönemin tasarımına ve malzemesine uygun olarak restore edilmiştir (Hunter Burkett \& Burdick 2019, 137). Mekânın içinde yapının ilk kullanımı hakkında görsel ve bilişsel bilgilendirmelere yer verilmiştir. Şu anda mekân restaurant olarak kullanılmaktadır. Mekânın adı eski işlevini vurgulamaktadır. Bununla birlikte içinde Roma tavernası konseptine uygun servis yapılarak tarihi özelliğini, işletmenin dikkat çekiciliğini artırmak için kullanmaktadır. $\mathrm{Bu}$ tutum, mekân içinde sunulan deneyimi özgün hale getirmektedir. Deneyimsel modülün tasarım boyutu, mekânı anlaşılması ve bu anlayışa göre var olan problemlerin belirlemesi ve yaratıcı çözümlerin geliştirilmesi doğrultusunda yapılandırılmasıdır. Özgün tasarım yapılanması kullanıcılar üzerinde pozitif yönlendirme yaparak mekânın popülerliğini yükseltmekte ve atmosferik etki yaratmaktadır.

Yukarıda belirtilen çerçevede yapılandırılan yeniden işlevlendirme eylemi, bir sonraki adımda kendi niteliğine uygun deneyimler ile donatılmaktadırlar. Bu şekilde özgün ve deneyimsel yapı, mekân içinde bütünsel olarak kullanılır hale gelmektedir. Stratejik deneyimsel modüle bütünsel olarak uyumlu mekânlarda daha yüksek bir beğeniye ulaşmak mümkün olabilmektedir. $\mathrm{Bu}$ amaç için mekân içinde beş duyuya hitap eden öğeler kullanılmaktadır. Bu şekilde hedef kitlenin duyu ve duygularına hizmet eden bütünleşik ve güçlü bir model oluşturulmaktadır.

Yeniden işlevlendirilmiş yapıda ziyaretçilerin duyularına bütünsel olarak hitap edebilmesi için görme, duyma, tatma, koklama ve dokunma duyularının tek tek mekân içinde uyarılmaları gerekmektedir. Görme duyusu en çok hitap edilen duyu olması nedeniyle en az etki alanına sahip olan duyudur. Buna karşın mekân ile bireye hitap etme amacı doğrultusunda ise en sık kullanılan duyudur. Yeniden işlevlendirilmiş mekânların tarihi ambiyanslarının etki alanı sıradan mekânlardan çok daha güçlüdür. Mekân yapılandırılması esnasında dönem fotoğraflarına, görsel uyarıcılara da yer verilerek bu algının daha heyecan verici hale gelmesi sağlanabilmektedir. En önemli etken ise hacmin varlığı ile yaşattı̆̆ ambiyansın korunmasıdır.

Kullanıcıların üzerinde yarattığı güçlü çağrışımlarla ses duyusu, önemli bir etki alanına sahiptir. Mekânın kendisine özel bir müziğinin olması mekânın hatırlanmasına ve burada yaşanan deneyimlerin bütünlenmesine yardımcıdır. Bununla birlikte kendisine özgü duyusal efektleri içinde barındırmayan diğer mekânlara göre daha özel bir konumda anılmasına neden olabilecek güce sahiptirler (Schmitt \& Simonson 1997, 104). 
Mekânlara özel, sadece o mekânın içinde ikram edilen ya da satılan lezzetlerin bulundurulması da akılda kalıcılığın sağlanması için kullanılan diğer bir duyu olan tat duyusunu uyandırmaktadır. Mekâna özel lezzetin/lerin varlığı deneyimin güçlenerek kalıcı duyulara dönüştürülmesine neden olmaktadır (Güzel 2013, 228). Lezzet deneyimleri ile ayrıca müşteri mutluluğu ve sadakati de sağlanabilmektedir (Hulten et al. 2009, 10).

Beynin deneyimleme ve öğrenme merkezi olan limbik sistemi uyaran yapısıyla koku duyusu çok güçlü ve akılda kalıcı niteliktedir (Schmitt \& Simonson 1997, 104). Mekâna özgü bir kokunun belirlenerek kullanılması bu nedenle mekânın ziyaretçi tarafından özel ve hatırlanır olmasını sağlayabilmektedir. Özel bir koku ile hatırlanır olmak ve kalıcı etki yaratmak mümkün olmaktadır (Keleş \& Çepni 2006, 73). Keşif ve tanımak dürtüsü ile dokunma duyusu yoğun bir şekilde kullanılmaktadır. Algının tamamlanması ve merakın giderilmesi bu duyunun tatmin edilmesi ile gerçekleştirilmektedir. Yeniden işlevlendirilmiş mekânı oluşturan öğelerin, yalın bir şekilde göz önüne konması ve dokunulabilir olmalarının sağlanması bu duyuya hitap eden bir yaklaşımdır.

Yaklaşım; her proje için kendi özgü çözümünü içinde barındırmaktadır. Anıtsal mekân içinde tarihi geçmişi olan yapının dokunulabilme özelliği, mekâna ve ait olduğu tarihi döneme yakın olma hissini vermektedir. Bu açıdan kendi içinde eşsiz bir deneyimi de içinde barındırmaktadır. Yeniden işlevlendirilen mekân içinde beş duyunun hepsine hitap eden öğeler ve servisler tanımlandığında bireylerin algılarına bütünsel olarak hitap etme ereği gerçekleştirilebilmektedir. Mekân, farklılaşarak akılda kalıcı ve etkileyici bir yapıya bürünmektedir.

Çalışmada araştırılan mekânlarda ziyaretçi ile optimal düzeyde bağ kurulabilmesi için duyular ile birlikte duygulara da hitap edilmektedir. Deneyimsel modülde birey ile mekân arasındaki bu ilişki stratejik olarak belirlenmiş duygular üzerinden sağlanmaktadır. Mekânın özelliklerini niteleyen bilişsel deneyimler aracılı̆̆ 1 ile bu amaç gerçekleştirilmektedir. Bu modüle göre yapılan deneyim tasarımıyla ziyaretçilerin şaşırtılması ve düşünmeye teşvik edilmesi sağlanmaktadır (Schmitt 1999, 138). Bilişsel deneyimler; bilmeceli öğelerin varlı̆̆ ile merak uyandırmak esasına göre tasarlanmaktadır. Tarihi nitelik üzerine düşündüren, merak ettiren mekânsal öğeler, mekân içinde bulundurulan broşürler veya çalışanların katılımı ile gerçekleştirilen performanslar (tiyatro, söyleşi, yarışma, v.b.); bu aktivitelere örnek oluşturmaktadır. Faaliyetlerin düzenlenmesi ve ziyaretçilerin katılımının sağlanması ile fiziksel deneyimler gerçekleştirilmektedir. Mekân içinde düzenlenen aktivitelere, alanlarında uzmanlaşmış kişilerin davet edilmesi ve mekânın niteliği hakkında bilgilendirici aktivitelerin oluşturulması ile duygusal deneyim modülü tamamlanmaktadır (Genç 2009, 72). Yeniden işlevlendirilmiş yapılardaki deneyimsel aktiviteler, mekânın inşa edildiği dönemi yansıtacak şekilde tasarlanmaktadır. Bu şekilde mekânın farklı özgünlüğü gözler önüne serilirken, ziyaretçi ile duygusal bağ da kurulabilmektedir. Bununla birlikte benzeri deneyimler; aynı zamanda yarat1c1lık ve öğrenmenin gerçekleşmesini eğlenceli bir platformda sağlamaktadırlar.

Belirtilen aktiviteler içinde ve bunlardan bağımsız olarak insanları bir araya getiren aktiviteler planlı bir şekilde yapılmaktadır. Sosyal deneyim tasarımında amaç; ziyaretçinin kendi imgelemindeki hayallere, ulaşmak istediği kişiliğe yaklaştığının hissettirmektir (Schmitt, 1999, 62). Akılda kalmak ve ziyaretçiler üzerinde etki bırakarak duygu oluşumunu sağlamaktadırlar. Doğaları gereği insanlar kendilerini bir gruba ait görmek istemektedirler. Ziyaretçiye etki alanı oluşturulmak istenen alan dahilinde birliktelik duygusunun yaşatılması ile bu deneyim sunulmaktadır. Bunun dışında mekân içinde konumlanan danışma alanında ziyaretçilere bilgi verilmesi, yöre hakkında bilgi verilmesi ve tüm yöresel gezi programları hakkında danışmanlık yapılması sosyal deneyimi tamamlayan ve ziyaretçilere güvenli bir ortamda olduklarını hissettiren bir deneyim çalışmasıdır.

\section{Materyal ve Yöntem}

Çalışmada örneklem olarak seçilen anıt yapılar, ilk olarak ilk işlevleri ve günümüzdeki işlevleri 
bakımından incelenmişlerdir. Bu inceleme sırasında yeniden işlevlendirme sırasında özellikle iç mekâna yapılan müdahaleler tespit edilmiştir. Hazırlanan kullanım sonrası değerlendirme anket formu kullanılarak önceden bu mekânları deneyimlemiş olan kullanıcılardan veri toplanmıştır. Toplanan veriler, excell kullanılarak yüzdelikler belirlenmiştir. Anket formunda yer alan sorular iki bölümden oluşmaktadır. İlk bölümde rastlantısal örnekleme yöntemiyle seçilen anket katılımcılarına kullanıcı memnuniyetini ölçmeye yönelik sorular sorulmuştur. İkinci bölümde ise anket katılımcılarından açı uçlu sorulara cevap vererek mekân deneyimlerini anlatmaları istenmiştir.

Araştırma kapsamındaki anıt yapıların incelenmesi için betimsel tarama modeli kullanılmıştır. Buna göre önce literatür taraması yapılmış, ardından da görsel kaynaklar incelenmiştir. Saha ziyaretleri sonucunda, araştırılacak yeniden işlevlendirilmiş tarihi yapıların fotoğrafları çekilerek belgeleme yapılmıştır. Antalya Kültür Varlıklarını Koruma Bölge kurulundan bölgedeki tarihi yapılar hakkında detaylı bilgi edinilmiştir. Kaleiçi ve Balbey Bölgesi’nde yapılan gözlemler neticesinde bölgenin çok sayıda turist tarafından ziyaret edildiği tespit edilmiştir. Elde edilen veriler ile anıt yapıların fiziksel durumu, ulaşılabilirliği, kullanıcıların yeni işlev hakkındaki fikirleri, konfor beklentileri ve iç mekân deneyimleri saha ziyareti sırasında iletişim bilgileri alınan kullanıcılara uygulanan çevrimiçi anketle belirlenmiştir.

Araştırma için Antalya Kaleiçi ve Balbey'de halen aktif olarak faaliyette bulunan 75 adet anıt yapı incelenmiş, bunların arasından 4 yapı araştırmaya dâhil edilmiştir. Bunlar; Mevlevihane, Balık Pazarı Burcu, Aya Yorgi Kilisesi ve Pazar Hamamı'dır (bkz. Fig. 1 ve Fig. 2). Bu anıt yapıların içinde bulunduğu Kaleiçi ve Balbey bölgeleri, özellikle yaz aylarında günün her saati kalabalık bir kullanıcı kitlesini barındırmaktadır. Bu bölgenin kullanıcıları, yerli-yabancı turistler ve işyeri sahipleri/çalışanlarından oluşmaktadır.

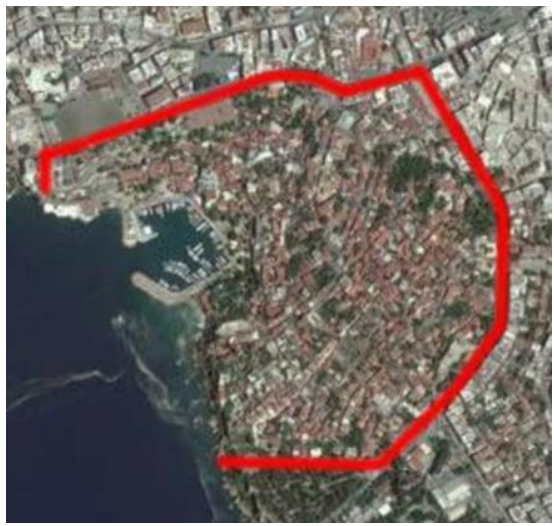

Fig. 1. Antalya Kaleiçi ve Balbey Sınırları (Çelik Başok 2016, 5)

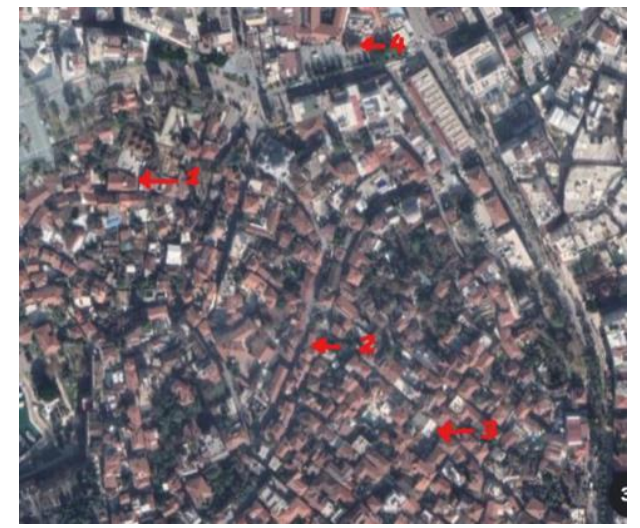

Fig. 2. İncelenen anıtsal yapılar: 1) Mevlevihane, 2) Balık Pazarı Burcu 3) Aya Yorgi Kilisesi 4) Pazar Hamamı (Google Earth, Nisan 2020)

Antalya Muratpaşa İlçesinde bulunan Kaleiçi, antik çağdan günümüze değin Antalya'nın kent merkezi olmuştur. Kalekapısı ve Hanlar Bölgesi, Balbey Mahallesi ve Haşimişcan Mahallesi ise bölgedeki surların dışında, bulunan ilk yerleşim alanları olarak kullanılmışlardır (Gül 2006, 121). Araştırma çerçevesinde incelenen yapılardan ilki olan Mevlevihane, Selçuklu döneminde inşa edilmiştir (Kepenek 2011, 50). Mevlevihane (36 53'11.4"N 3042'15.7"E); Kaleiçi'nin kuzeyinde, Selçuk Mahallesi yer almaktadır. Kaleiçi Kentsel ve Arkeolojik Sit Alanı içerisinde olan bu bölge, 166 ada, 11 parseldedir. Günümüzde, Mevlevi Müzesi olarak yeniden işlevlendirilmiştir (bkz. Fig. 2). Eski Eserler ve Müzeler Genel Müdürlüğü’nün A-20, 5,15.12.1979 sayılı kararı ile tescil edilen Mevlevihane yapısının mülkiyeti Vakıflar 'da ve Antalya Kültür ve Turizm Müdürlüğü’ne tahsislidir (K.V.K.E. Envanter no. 54).

Evliya Çelebi’nin anlatımından yapının 17. yüzyılda Mevlevihane olarak kullanıldığı 
anlaşılmaktadır (Numan 1982, 130). Ancak, bu bilgi dışında yapım tarihine dair herhangi bir kaynak bulunmamaktadır. Mekân, 13. yüzyılda Tekeli Mehmet Paşa tarafından Mevlevihane olarak kullanımına atanmıştır (Numan 1982, 125). Yapı, iki katlı ve kâgirdir. Beylikler dönemine ait Antalya Mevlevihanesi, Osmanlı ve Cumhuriyet dönemlerinde onarımlar geçirerek, özgün tasarımını genel hatlarıyla günümüze kadar korumuştur (Sönmez 2008, 33). Enine dikdörtgen planlı olan Mevlevihane'nin iç kısmında basamaklı yükseltilere yer verilmiştir. Mekânın orta avlusu bulunmaktadır. Yapının alt katında dervişler ve misafirler için ocaklı oturma odas1, yatak odaları konumlandırılmıştır. Üst katta ise ocaklı postnişin odası, oturma odas1, şeyh dairesi ve yatak odalarına yer verilmiştir. Mekânın üstünde bulunan kubbe üzerinde altıgen kasnaklı bir fener bulunmaktadır. Üstü kiremitlerle örtülü mekânın bacaları ise kesme taştır (K.V.K.E. Envanter no. 54).

Osmanlı döneminde de tadilat geçirdiği bilinen yapı, Vakıflar genel müdürlüğü tarafından 1955, 1961, 1972, 1984 yıllarında onarılmış ancak büyük değişiklikler olmamıştır (bkz. Fig. 3, Fig. 4, Fig. 5 ve Fig. 6), (K.V.K.E. Envanter no. 54). 1972 yılında mekân Güzel Sanatlar Galerisi olarak işlevlendirildiğinde, iç ve dış sıvaları yenilemiştir. Bununla birlikte duvarlara zarar vermeyecek şekilde aydınlatma tasarımı adapte edilmiştir (Çimrin 2018, Sabah Gazetesi). 2009 yılında ise mekânın ihtiyaç duyduğu ufak tefek tamiratlar yapılmıştır. 2014 yılında başlanan ve 2016 yılında bitirilen yeni bir restorasyonla, binanın kiremitleri yenilenmiş ve dış sıvaları sökülerek somut hacim günümüzdeki görünümüne bürünmüştür (Çimrin 2018, Sabah Gazetesi), (bkz. Fig. 7 ve Fig. 8). Yap1, 2019'da Mevlevihane Müze olarak hizmet vermeye başlamıştır (Deniz 2019, Hürriyet Gazetesi).

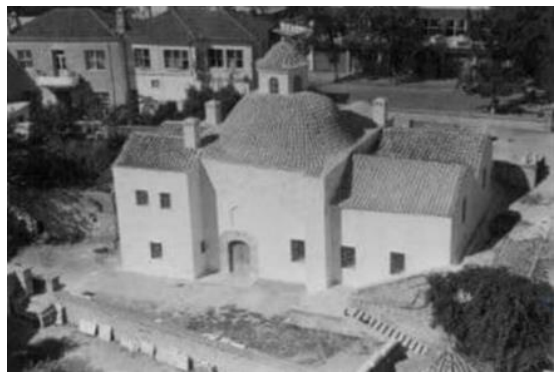

Fig. 3. Mevlevihane 13.10.1962 (Tarik Göksu arşivinden)

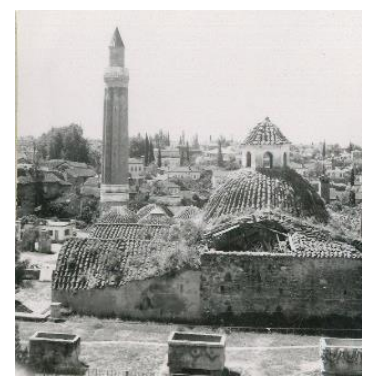

Fig. 4. 1980'li y1llarda Mevlevihane (Antalya KUDEB arşivi)

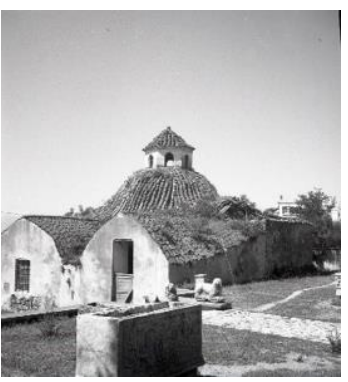

Fig. 5. 1980'li yıllarda Mevlevihane (Antalya KUDEB arşivi)

Selçuklu döneminden günümüze kadar gelen Mevlevihane Müzesi’nin yeniden işlevlendirilmesinde tarihi odaklılık adına yapılan vurgu göze çarpmaktadır (bkz. Fig 9 ve Fig. 10). Bu duyarlılık çerçevesinde 2016 yılında yapılan onarımda binanın sıvaları sökülmüştür. Fakat binanın orijinal halinin sıvalı olup olmadığı hakkında farklı düşünceler bulunmaktadır.

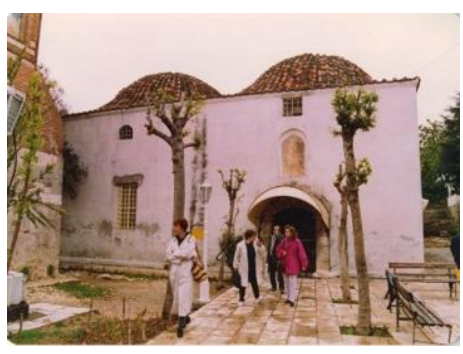

Fig. 6. 2000'lerde Mevlevihane'nin Güzel Sanatlar Galerisi olarak

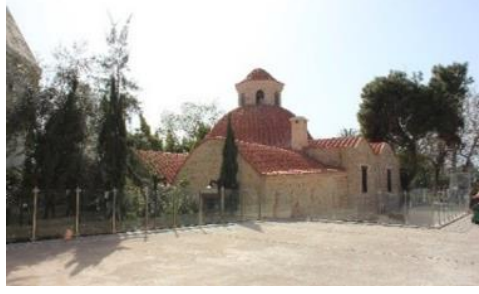

Fig. 7. Günümüzde Mevlevihane (Antalya KUDEB arşivi)

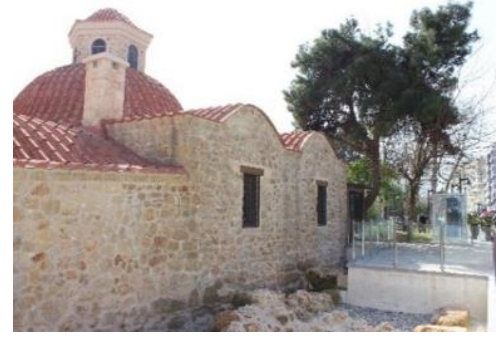

Fig. 8. Günümüzde Mevlevihane (Antalya KUDEB arşivi) 


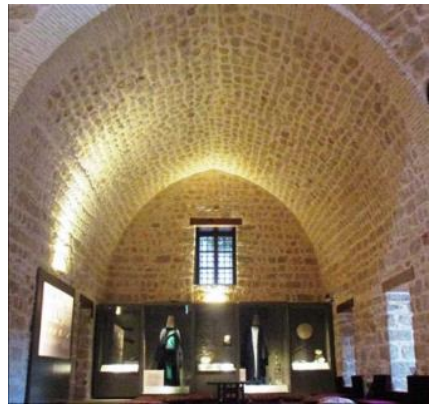

Fig. 9. Mevlevihane İç Mekan görünümü (https://www.kulturportali.gov.tr/turkiye/antalya/ gezilecekyer/mevlevihane-muzesi, Şubat, 2020)

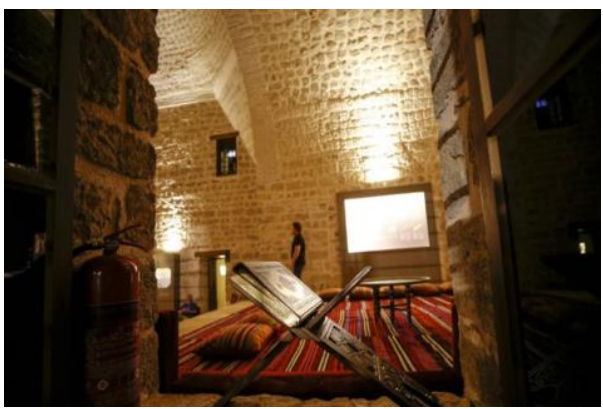

Fig. 10. İç Mekan görünümü Mevlevihane (https://www.aa.com.tr/tr/turkiye/antalyada-762yillik-mevlevihane-yeniden-hizmeteacildi/1168942\#, Şubat 2020)

Mekân, Mevlevihane Müzesi olarak yeniden işlevlendirilmiştir. Mekâna verilen yeni fonksiyon, orijinal işlevi yansıtması ve tarihi ruhu yaşatması açısından kavramsal bir birlik oluşturmaktadır. Bu da ziyaretçilerin mekân içinde bulunmaları sırasında tarihi mekânı ve orijinal fonksiyonunu birebir hissetmelerini sağlamaktadır. Bu yaklaşım, algının uyarılmasını ve öğrenmenin yüksek derecede efektif hale getirilebilmesini sağlamaktadır. Çünkü nesnellik ve öznelliğe hitap eden deneyimler tümel bilince yöneltilebilmektedir ve bu mefhum hafizada kalıcilık sonucunu doğurmaktadır (Dewey 2011, 123). Mekân içindeki sergi tasarımı beş duyuya hitap edecek şekilde yapılandırılmamıştır. Mekân içinde duyusal, duygusal, bilişsel, fiziksel ve sosyal deneyim modüllerine bütünsel olarak hitap edilmemiş olsa da mekânın Mevlevilik hakkında içerdiği bilgilendirmeler ve objeleri içinde barındırmasıyla atmosferik bir etki alanına sahiptir. $\mathrm{Bu}$ yönleri ile Mevlevihane Müzesi dönemin ruhunu ziyaretçilere yansitabilmektedir.

Tarihi Sit Alanı içinde yer alan Balık Pazarı Burcu (3653'08.7"N 30²2'22.2"E); Kaleiçi'nin merkezinde; Balıkpazarı Sokak, Hıdırlık Sokak, Zafer Sokak ve Paşa Camii Sokak olmak üzere dört sokağın kesişme noktasında yer almaktadır (Sönmez 2008, 170). Kaleiçi Kentsel ve Arkeolojik Sit Alanı içerisinde 56 ada, 1 parselde bulunmaktadır (bkz. Fig. 2). Alttan geçitli bir kapı burcu olan Balık Pazarı Burcunun alt katı alışveriş mekânı olarak yeniden işlevlendirilmiştir (K.V.K.E. Envanter no. 1), (bkz. Fig. 11 ve Fig. 12). İki kapısı da görülebilen burcun giriş katı tek bölümlüdür. Burcun iç bölümü basık kemeri ile Selçuklu Dönemi'nin izlerini taşımaktayken, dış bölümünde ise kapıların görünümü sivri kemerleri ve taş örgü kullanımı ile Attalos Dönemi'ni yansıtmaktadır (Sönmez 2008, 170). Günümüze kadar bütünüyle gelememiş olan üst bölüm iki bölümlü olarak inşa edilmiştir. Doğu bölümde güneykuzey yönünde tonoz konumlanmışken, batı bölümde doğu-batı yönünde tonozdur (Sönmez 2008, 170). Burç üzerinde iki adet yazıt bulunmuştur. Günümüze ulaşamayan yazıtlardan ilkinde;

Bu binanin 622 (M.1225) yllında Kelükvan bin Sinbad-ı Konevi'nin zaylf eliyle yapılmasını Keykubat bin Keyhüsrev emretti (K.V.K.E. Envanter no. 1).

Yazıtlardan ikincisinde ise şu bilgi verilmektedir:

Bu binanın 622 (M.1225) yılında Abd-i Zaif Şavik bin Vay eliyle yapılmasını Keykubad bin Keyhüsrevin emretti (K.V.K.E. Envanter no. 1). 


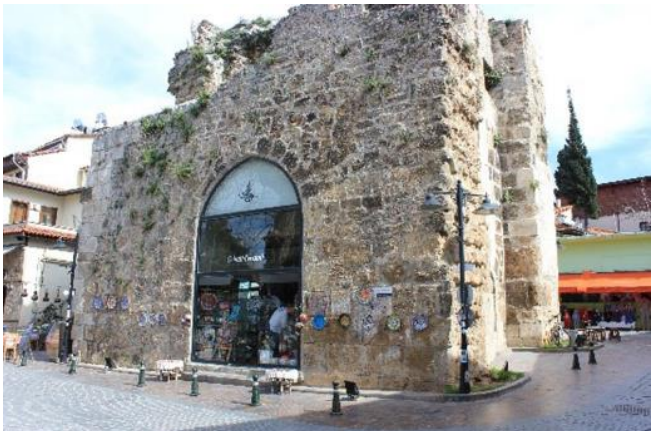

Fig. 11. Balık Pazarı Burcu (Antalya KUDEB arşivinden)

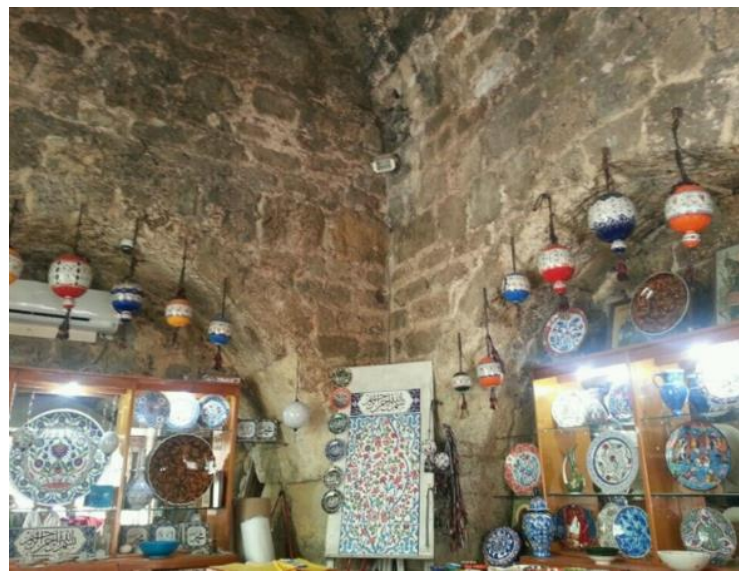

Fig. 13. Balık Pazarı Burcu https://tr.foursquare.com/v/cobaltceramic/4fe1b8316d86cb9bc26e533c, Şubat, 2020

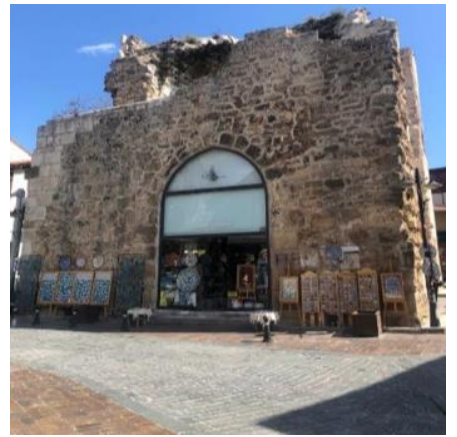

Fig. 12. Balık Burcu Pazarı (Berna İskifoğlu arşivinden)

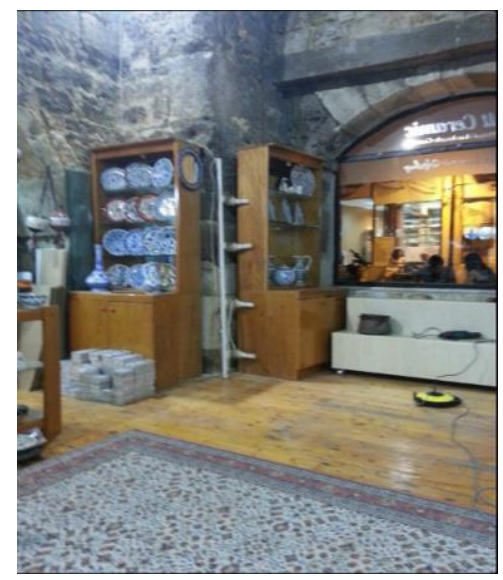

Fig. 14. Balık Pazarı Burcu https://tr.foursquare.com/v/cobaltceramic/4fe $1 b 8316 d 86 c b 9 b c 26 e 533 c$, Şubat, 2020

Günümüzde alışveriş mekanı olarak işlevlendirilen Balık Pazarı Burcu, Roma Dönemi'nde inşa edilmiş olup Bizans, Selçuklu ve Osmanlı Dönemi'nde onarım görmüștür (K.V.K.E. Envanter no. 1), (Sönmez 2008, 170). Antik görünümü dış cephede doğal dokunun tamamen korunmas1 ile muhafaza edilmiş mekân bulunduğu konumda ilgi uyandıran bir yapıya sahiptir. Burcun alışveriş mekânı olarak işlevlendirilmesinde minimal mimari müdahalede bulunulmuştur. $\mathrm{Bu}$ da mekânın atmosferik etkisini artırmaktadır. Bununla birlikte iç mekân donatısının tekrar gözden geçirilmesi gerektiği düşünülmektedir (bkz. Fig 13 ve Fig 14). Mekânın içinde folklorik hediyelik eşyaların satılması ise mekânın sahip olduğu tarihi atmosfer ile örtüşür niteliktedir. Deneyimsel modül tam anlamıyla mekân içinde kullanılmamış olsa da geliştirilebilir niteliktedir.

Aya Yorgi (Agios Georgios) Kilisesi (3653'03.1"N 30² $\left.{ }^{\circ} 27.1 " \mathrm{E}\right)$; Kaleiçi bölgesinin güneyinde, Kılınçarslan, Kocatepe Sokakta bulunmaktadır. Kaleiçi Kentsel ve Arkeolojik Sit Alanı içerisinde, 133 ada 13 parseldedir (bkz. Fig. 2). Tek bir hacimden oluşan mekân dikdörtgen planl1dır. Kilisenin üstü tonoz ile örtülüdür. Dikdörtgen planlı olan Aya Yorgi Kilisesi tek nefli, tonoz örtülü ve kilisenin cenneti simgeleyen tavanı, mavinin farklı tonlarında yalın kalem işi ve alçı bezeklerle süslüdür. Aziz Georgios adına yapılan bu Ortodoks Kilisesi'nin kitabesinde Türkçe 1863 yılında onarım gördüğü belirtilmektedir (K.V.K.E. Envanter no. 30). 1920'li yıllarda yapılan nüfus mübadelesi nedeniyle kilise cemaati göç etmiş ve mekân uzun yıllar boyunca depo olarak kullanılmıştır. Bu dönemde ahşap iç mekân öğelerinin bazılarını kaybetmiştir (Kaplan 2018, 125). Kilise 1993-95 yı1ları arasında süren restorasyon çalışmalarından sonra 1996 'Sergi Salonu' olarak kullanılmaya başlanmıştır (Çelik Başok 2016, 47), (bkz. Fig. 15, Fig. 16 ve Fig. 17). 


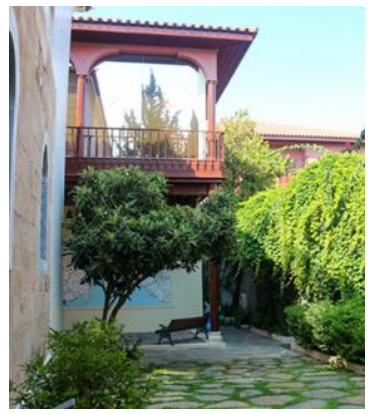

Fig. 15. AyaYorgi Kilisesi

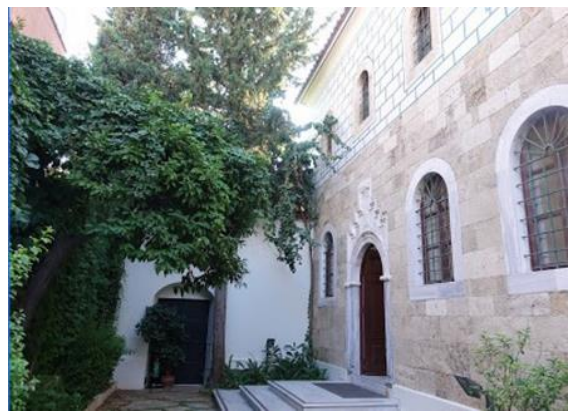

Fig. 16. Aya Yorgi Kilisesi Görünüş 2 (Antalya KUDEB arşivi)

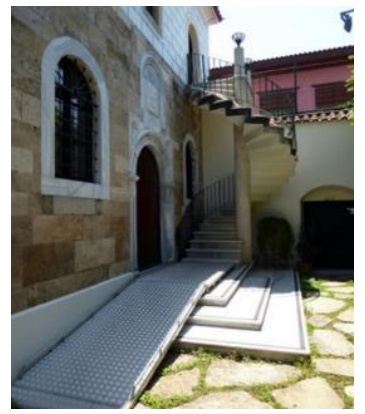

Fig. 17. Aya Yorgi Kilisesi Görünüş

Mekân, günümüzde içinde Suna ve İnan Kıraç koleksiyonuna ait kültür ve sanat eserlerinin sergilendiği, Suna ve İnan Kıraç Kaleiçi Müzesi olarak hizmet vermektedir (bkz. Fig. 18 ve Fig. 19).

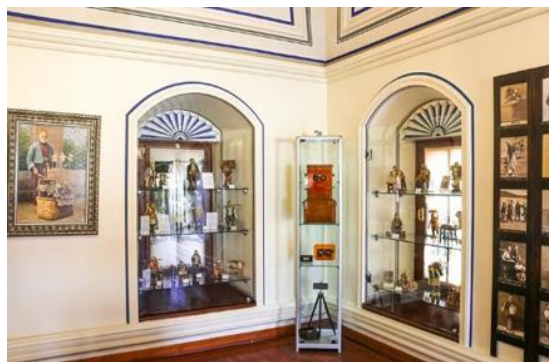

Fig. 18. Yeniden İşlevlendirilmiş Aya Yorgi Kilisesi İç Mekânı.

https://akmed.ku.edu.tr/kaleici-muzesi/ayayorgi-kilisesi/, Mart 2020

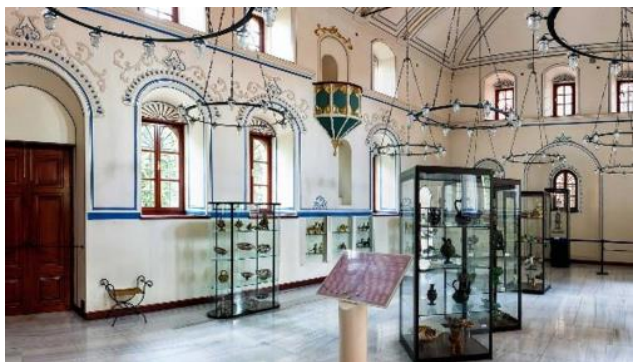

Fig. 19. Yeniden İşlevlendirilmiş Aya Yorgi Kilisesi İç Mekânı.

https://akmed.ku.edu.tr/kaleici-muzesi/ayayorgi-kilisesi/, Mart 2020

Suna ve İnan Kıraç Müzesi'nin tarihi değerlere sadık kalınarak yeniden işlevlendirilmesi amaçlanmıştır. Kilise, yeniden işlevlendirme öncesi uzun bir dönem depo olarak kullanılmıştır. 1996 yılında biten yeniden işlevlendirme ile birlikte Müze ve Sergi Salonu olarak hizmet vermeye başlayan mekân içinde deneyimsel aktiviteler yürütülmektedir. Yeniden işlevlendirilmiş mekânlardaki tarihi duyarlılık gerekleri bu mekânda optimal düzeyde yaşatılmaktadır. Bunun nedeni hiç şüphesiz mekânın bir bilimsel enstitü donanımın parçası olarak değerlendirilmiş olmasıdır. Mekânın ilk inşa edildiği dönem ve özellikleri, bilimsel düzeyde araştırılarak yeniden işlevlendirme sürecinde kullanılmıştır. Bu asli gerekliliğin dışında müzenin bir bilimsel araştırma merkezinin parçası olması deneyimsel bağlamda ziyaretçilere büyük kazanımlar sağlamaktadır. Mekânın içinde sosyal, bilişsel ve fiziksel deneyimsel aktiviteler yaygın bir şekilde kullanılmaktadır. Tesisin içinde bulunan akademik yapılanma, kütüphane, sergi salonları, konunun uzmanlarınca düzenlenen konferanslar, öğrenci destek programları ve çalışma alanları bu modülü bütünleyen niteliğe sahiptir. Bununla birlikte mekân edinilen deneyimin dönüşümü ile bilginin oluştuğunu anlatan deneyimsel öğrenme teorisinin de uygulanabileceği özgün bir platforma sahiptir (Kolb et al. 2001, 228). Sonuç olarak mekân hitap ettiği kitlenin ihtiyaçlarına cevap veren bir ilgi odağı haline gelmiştir.

Pazar Hamamı (36 53'15.5"N 3042'25.0"E); Kaleiçi'nde bulunan saat kulesinin çaprazında Hanlar Bölgesi Koruma Alanı içerisinde bulunan Balbey Mahallesi'nde yer almaktadır (bkz. Fig. 2). Antalya'nın en önemli anıt eserleri arasında olan Pazar Hamamı'nın inşa kitabesi maalesef günümüze ulaşamamıştır (bk. Fig. 20, Fig. 21 ve Fig 22). 


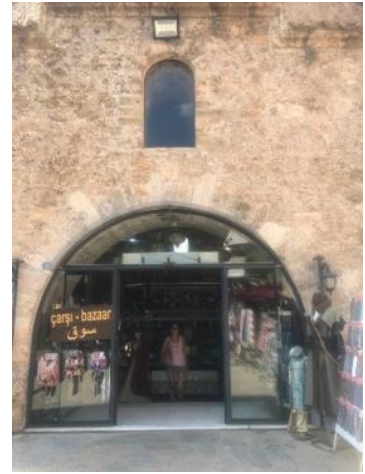

Fig. 20. Pazar Hamam1, 2020. A. Durukan arsivi

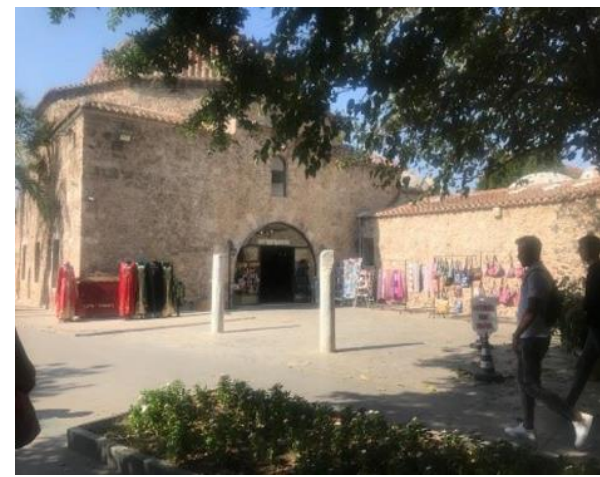

Fig. 21. Yeniden İşlevlendirilmiş Pazar Hamamı

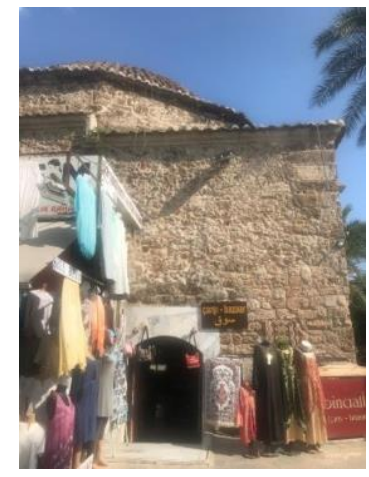

Fig. 22. Pazar Hamam1, 2020

Pazar Hamamı tarihçesine dair ilk bulgu Evliya Çelebi'den gelmektedir. 1671-1672 yılında Antalya'ya gelen Evliya Çelebi, şehir merkezinde Paşa Hamamı'nın olduğundan bahsetmektedir (Evliya Çelebi 2016, 166). 1811-1812 yılına ait vakıf belgesinde mekânın adı geçmektedir (Kılıç 2015, 96). Hamam içinde yaşmak kullanımı, kurna tasarımı ve tuvaletlerin konumlanması gibi detaylar Pazar Hamamının 16. yüzyılın ikinci yarısında yapıldığını göstermektedir (Önge 1989, 256). Pazar Hamamı'nın günümüze ulaşan planı incelendiğinde; kadınlara ve erkeklere hizmet veren bir çifte hamam olarak tasarlandığı anlaşılmaktadır. Hamam kadınlara ve erkeklere tahsis edilen iki alandan oluşmaktadır. Eski eser ve anıt statüsünde 1979 yılında tescillenmiş olan hamam (AVBM, 070001038-BN001 numaralı bilgi yazıs1), günümüzde turistik alışveriş mekanı olarak yeniden işlevlendirilmiştir.

Alışveriş mekânı olarak yeniden işlevlendirilmiş anıtsal yapının, duvarlarındaki sıvalar orijinal değildir. Mekân öğesi olan duvarlar, zemin, sekiler ve musluklar orijinal haliyle günümüze kadar gelememiştir. Bahsi geçen bu detaylar dışında yeniden işlevlendirmede tarihi dokuya bağlı kalmaya çalışılmıştır. Anıtsal yapının etkileyici atmosferik bir etkisi bulunmaktadır. Hamamın taş duvarları ve kubbesi dış cepheden ilgi çeken bir yapıya sahiptir. Alışveriş mekânın içinde turistik eşyalar satılmaktadır. Bu durum, deneyimsel modülün anı oluşturma kavramına paralel bir tutumdur. Hatıra oluşturmak ve hatırlanmak için önemli bir deneyim alanı bu şekilde tamamlanmaktadır. Hamamın 1lıklık bölümünde kurna, sabun ve kese gibi orijinal mekânın işlevine gönderme yapan hediyelikler bulunmaktadır. Mekân deneyimsel modüle uygun bir yapılanma içindedir. Ufak dokunuşlarla deneyimsel modülün tatbik edilmesinde bütünlük sağlanabilecek durumdadır (bk. Fig. 23, Fig. 24 ve Fig 25).

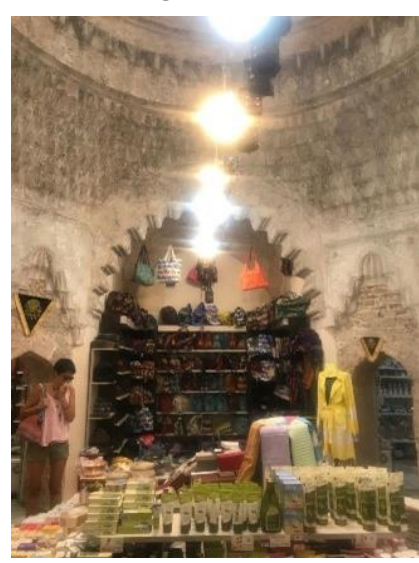

Fig. 23 Pazar Hamamı içinde satış reyonu, 2020 (A. Durukan arşivi)

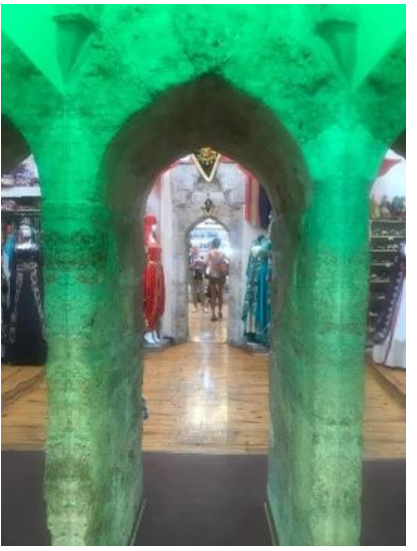

Fig. 24 Pazar Hamamı 2020 iç mekân kullanımından kare (A. Durukan arşivi)

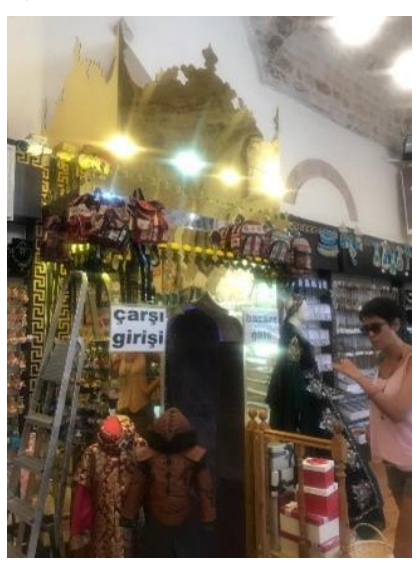

Fig. 25 Pazar hamamı içinde yapılandırılan satış reyonu (A. Durukan arşivi) 


\section{Bulgular ve Değerlendirme}

Kaleiçi ve Balbey, Kentsel ve III. Derece Arkeolojik Sit Alanı'nı kapsamaktadır. Batıda Yat Limanı ve Akdeniz, kuzeyde Cumhuriyet Caddesi, doğusunda Atatürk Caddesi, güney ve güneydoğusunda ise Karaalioğlu Parkı (I. ve III. Derece Doğal Sit Alanı) ile sınırlandırılmıştır. Çalışma sahası olarak seçilen Kaleiçi ve Balbey, Antalya kentinin merkezi niteliğindedir.

Yerinde yapılan gözlemler neticesinde çalışma sahası olarak seçilen Antalya Kaleiçi ve Balbey bölgesinin yeniden işlevlendirme ve koruma konusunda oldukça başarılı olduğu görülmüştür. Yapılan alan çalışmasında belirlenen mekânlarda gözlem ve belgeleme yapılmış, kullanıcılarla iletişim kurulmuştur. Yerinde yapılan gözlem ve görüşmeler sonucunda daha sonra yapılacak anket için 59 kullanıcıdan iletişim bilgileri alınmıştır. Yapılan gözlem ve belgeleme çalışmaları sırasında kullanıcıların davranışları da gözlemlenmiştir. Rastlantısal örnekleme yöntemi ile seçilen kullanıcıların araştırma sahası içinde belirlenen mekânları ziyaret etmiş olmaları belirleyici olmuştur.

Saha ziyareti sonrası iletişim bilgileri alınan kullanıcılara, çevrimiçi olarak kullanım sonrası değerlendirme anketi uygulaması yapılmıştır. Ankette kullanıcıların mekân hakkındaki değerlendirmelerini yapmaları için açı ve kapalı uçlu sorular bir arada sorulmuştur. Açık uçlu soruların cevapları belirlenen kodlar dahilince çözümlenmiştir. Elde edilen veriler ile anıt yapıların fiziksel durumu, ulaşılabilirliği, kullanıcıların yeni işlev hakkındaki fikirleri, konfor beklentileri yanında iç mekân deneyimleri de saha ziyareti sırasında iletişim bilgileri alınan kullanıcılara uygulanan çevrimiçi anketle belirlenmiştir.

Kullanıcıların saha araştırmasında belirlenen yapıların genel görünümünden memnun kaldıkları anlaşılmıştır $(\% 70,69)$. Bununla birlikte kullanıcıların yapıların bulunduğu çevreden daha yüksek düzeyde memnun oldukları görülmüştür $(\% 72,10)$. Bu duruma yapıların bulunduğu çevrenin bütüncül olarak düşünülerek alınan, tarihi çevreyi koruma kararlarının neden olduğu söylenebilir. Koruma ve yeniden işlevlendirme konusunda Kaleiçi ve Balbey'de oldukça yerinde uygulamalar yapıldığ 1 ve bu uygulamalardan kullanıcıların memnuniyet düzeylerinin yüksek olduğu görülmüştür. Bu uygulamaları yapıların çevreleriyle birlikte kullanıcı üzerinde olumlu etki bırakmaları turizm açısından da oldukça etkili olmaktadır. Yapıların bulunduğu çevreye ulaşım kullanıcılar tarafından en yüksek memnuniyet seviyesine sahiptir (\%77,24). Bu durum çevresiyle birlikte değerlendirilmesi gereken yeniden işlevlendirilmiş tarihi yapılar açısından oldukça değerli bir kazanımdır. Kullanıcı memnuniyetini en fazla düşüren konuların ise restorasyondan kaynaklanan sorunlar olduğu belirlenmiştir $(\% 67,59)$. Buna rağmen yapıların anıtsal özelliklerinin kullanıcılar tarafından fark edilerek memnuniyet düzeylerinde belirleyici olduğu da anket çalışmasıyla anlaşılmıştır $(\% 74,8)$. Saha araştırmasında incelenen yapıların teknolojik olanaklarının (internet vb.) kullanıcılar tarafindan yeterli düzeyde görülmediği $(\% 64,48)$ anlaşılmış bu yönlerin geliştirilmeye muhtaç olduğu belirlenmiştir. Kullanıcıların geneli, yapıların mekân organizasyonundan memnun olduklarını belirtmişlerdir $(\% 68,62)$. Bununla birlikte ıslak hacimlerden de benzer düzeyde memnuniyet duyulduğu anlaşılmıştır $(\% 67,6)$. Mekânların yüksek tavanlı olmaları ve geniş açıklıklara sahip olmaları, mekânın boyutları $(\% 75,5)$, malzeme kullanımı $(\% 75,9)$ ve yapının genel büyüklüğü $(\% 78)$ bakımından kullanıcı memnuniyetini olumlu yönde etkilemiştir. Kullanıcı sirkülasyonun oldukça fazla olduğu ve ziyaretçi sayısının yüksek olduğu göz önüne alındığında bu durumun oldukça olumlu olduğu anlaşılmaktadır. Yeniden işlevlendirilen yapılarda iç çevre kalitesinin önemli bir öğesi olan sıcaklık, kullanıcılar tarafından oldukça olumlu bulunmuştur (\%75), buna karşın mekânın kokusundan aynı düzeyde memnuniyet sağlanamadığı görülmüştür $(\% 66,6)$. Bunun nedeni dışarıdan gelen kirleticiler ve yiyecek-içecekler olarak belirtilmiştir. Deneyim odaklı mekânlarda kokunun belirleyici bir faktör olduğu bilinmektedir. Kullanıcıların büyük çoğunluğu mekânın kendine özgü bir kokusu olduğunu söylemiştir $(\% 81,03)$. 
İç çevre kalitesi konusunda bir diğer önemli faktör de aydınlatmadır. Daha çok yapay aydınlatmanın kullanıldığı araştırmada incelenen yeniden işlevlendirilmiş mekânlarda aydınlatmadan duyulan memnuniyet oldukça yüksek düzeydedir $(\% 74,1)$. Buna karşın incelenen mekânlar kullanıcılar tarafından gürültü düzeyi yüksek bulunmuştur. Bu durum, akustik bakımdan memnuniyeti olumsuz yönde etkilemiştir $(\% 64,83)$. Ses düzeyinden rahatsızlık duyulmasına neden olmuştur $(\% 64,83)$. Bunun yanında kullanıcılar konuşma gizliliğinin sağlanamadığını da belirtmişlerdir $(\% 66,9)$.

Yapının iç mekân ve mobilyalarından duyulan memnuniyet düzeyi oldukça yüksektir (\%70,7). Bu durum deneyim odaklı mekânlar bakımından oldukça olumlu olarak görülmüştür. Kullanıcılar mekân içinde kendilerini rahat ve mutlu hissettiklerini söylemişlerdir (\%67,24). Yapılan araştırmada en düşük memnuniyet düzeyini mekânın tadı almıştır $(\% 44,82)$. Bu durum yeniden işlevlendirilen mekânlarda mekâna özgü bir yiyecek-içeceğin olmamasından ya da yeni işlevin mekânı tanıtıcı özgün bir nitelik taşımamasından kaynaklanabilir. Kullanıcıların büyük çoğunluğu mekânın sağladığı tarihi atmosferden memnun kaldıklarını belirmişleridir $(\% 72,07)$. Buna karşın mekâna ait bilgilendirmelerden aynı düzeyde memnuniyet duyulmadığı görülmüştür $(\% 64,24)$. Buna bağlı olarak mekânı anlatan kitapçık ve broşürlerden memnuniyet de düşük düzeydedir $(\% 68,28)$. Bu konuda en düşük memnuniyet düzeyine ise mekânın tarihi geçmişini anlatan görsellerden duyulan memnuniyet sahiptir $(\% 56,89)$. Bu durumda yeniden işlevlendirilen mekânlarda mekânın tarihine ait özelliklerin anlatılması deneyim yaşatmak bakımından da yerinde olacaktır. Bununla birlikte mekânda çalışan kimselerin de yapı hakkında bilgi sahibi olmaları gerektiği anlaşılmıştır $(\% 55,17)$.

Genel olarak kullanıcıların araştırılan mekânlarda yaşadıkları deneyimden memnun kaldıkları görülmüştür $(\% 66,55)$. Mekân içinde düzenlenen aktivitelerin mekânın dokusuna uygun bulunduğu ifade edilmiştir. Mekân içindeki tanıtıcı ve eğlendirici faaliyetlerden memnun kaldıklarını ifade etmelerine rağmen $(\% 65,17)$ deneyim odaklı mekân yaratmak için yeterli olmadıkları anlaşılmıştır. Elde edilen veriler incelendiğinde araştırmada incelenen mekânların deneyim sağlamada oldukça etkili oldukları görülmüştür. Ancak deneyim kazandırmaya yönelik eylemlerin yetersiz olduğu anlaşılmıştır. Yapılan araştırmada demografik yapıya göre farklılıklar tespit edilmiştir. Kadınların mekânsal özellikler, donanım ve atmosfer hakkında daha duyarlı oldukları belirlenmiştir.

Kullanıcılara bulundukları mekânda nasıl bir deneyim yaşadıkları sorulduğunda çok çeşitli cevaplar verdikleri görülmüştür. "Mekânın tarihsel dokusu mistik havası iyiydi", "Kendine has bir yapısı var", "Güzeldi, atmosfer harikaydı", "Tarih kokuyordu" gibi cevaplar verdikleri görülmüşsür. $\mathrm{Bu}$ durum yeniden işlevlendirilen mekânların deneyim odaklı mekân yaratmada bir altyapıya sahip olmalarıyla birlikte bu durumun fiziksel çevre koşulları ve çevresel faktörlerle desteklenmesi gerektiğini göstermektedir.

\section{Sonuç ve Tartışma}

Kaleiçi ve Balbey'de bulunan Anıtsal mekânların, deneyim alanlarının değerlendirilmesiyle birlikte mekânın ziyaretçi ile interaktif bir bağ içine girmesi sağlanabilir. Bu bölgedeki yapılar için kurgulanacak deneyimlerin tiyatral bir yaklaşım ile ziyaretçilerin içinde yer alabilecekleri mekân ve yöre ile alakalı konularda seçilmesi gerekmektedir. Deneyim önerileri, konu ile ilgili yapılacak araştırmalarla çeşitlenebilecek bir yapıya sahiptir. Mekân bu tür aktiviteleri ile ziyaretçi ile bağ kurup kendi kültürel öğelerini, anlatır hale getirilebilecektir.

Kullanıcılar yeni yerleri deneyimlemek istemekle birlikte bu aktiviteleri yakınları ile paylaşmayı da talep etmektedirler. Böylece otantik bir ortamın içinde paylaşımlarda bulunarak sosyalleşme firsatlarını aramaktadırlar. $\mathrm{Bu}$ nedenle turistik mekânların içinde ve dışında sosyalleşme için alanların tasarlanması bu ihtiyaçlara cevap verebilecektir. 
Deneyimsel modüle göre tasarlanmış mekân içinde sunulan deneyimlerin akılda kalıcı olmaları için deneyimler, tematik tasarımlar ile farklılaşarak mekânı daha akılda kalır bir şekle dönüştürmelidir. Deneyimsel modül, bu amaçlar doğrultusunda mekânın popülerliğini ve karlılığını artıracak niteliktedir. Aynı zamanda güçlü şekilde yapılandırılmış mekânların yöre turizmine ve tanınırlığına da büyük katkı sağlayacağı düşünülmektedir.

Yapılan görsel analiz sonucunda elde edilen veriler, Kaleiçi ve Balbey'de yeniden işlevlendirilen mekânların koruma restorasyon bakımından çevresi ile uyum içinde olduğu ancak yapıların kullanıcılara deneyim sağlayamadığ kapasitelerinin üzerinde kullanılması, yeni işlevden kaynaklanan sorunlar, yeni işlevin deneyim sağlamaya odaklı olmaması gösterilebilir. Kullanıcılara yeterli düzeyde konfor sağlamak amacıyla yapıya yapılan müdahalelerin pek çok yerde kullanıcı memnuniyetini olumsuz yönde etkilediği gözlemlenmiştir. Bu durumda yapıları deneyimleyen kitlenin konfordan farklı beklentileri olduğu anlaşılmıştır. Örneğin mekâna has tatların oluşturulması ve sunulması ile bu beklentilerin karşılanabileceği görülmüsstür. Bunun yanında yapının özgün kimliğine ait özelliklerin de kullanıcılar tarafından bilinmek istendiği anlaşılmıştır. Kullanıcıların böyle bir taleplerinin olması, yapıya ait bilgilere ulaşmadaki memnuniyetsizliklerinden kaynaklandığı fark edilmiştir.

Yapıların özgün özellikleri dikkate alınarak verilen yeni işlevin yapının yaşatılmasında etkili olduğu açıktır. Ancak yapıya yeni işlev verilirken yapının özgün işlevinin de unutulmaması gerektiği çalışma sonunda anlaşılmıştı. Özgün işlevini koruyamasa bile ilk işlevinden özellikler taşıyan yapılar, kullanıcılara bekledikleri tarihsel deneyimi sunabilmişlerdir. Böylece daha akılda kalıcı olabilmişlerdir. Buna karşın yapıları işletenlerin kullanıcılara deneyim sağlama ve yapının tarihi değerini vurgulama bakımından yetersiz kaldığı görülmüştür. Bu bakımdan tarihi çevrede işletme sahibi ve çalışanların öncelikle bulundukları çevre ile ilgili kapsamlı bilgi sahibi olmalarına çalışılmalıdır. Bunun yanında bu tür yeniden işlevlendirilen yapıların kendi haline bırakılmaması, periyodik aralıklarla bölgesel otoriteler bakımından yapı ve kullanım konularında denetlenmesi korumanın sürdürülmesi bakımından da gerekli görülmüştür. Araştırma sonuçları kullanıcı memnuniyetinin büyük ölçüde tarihi yapının kendine has özelliklerinden kaynaklandığı yönündedir. $\mathrm{Bu}$ durumda yapmamız gereken yapının kullanıcılar tarafından dikkat çekilen özelliklerinin öne çıkarılarak çevresel faktörlerle desteklenmesi olmalıdır. Bu bakış açısı ile öncelik kullanıcı konforunu sağlamak yerine yapının tarihi özelliklerinin öne çıkarılması olmalıdır. Yapılara kullanıcı istekleri doğrultusunda yapıya uymayan işlevler verilmemelidir. Mevcutta yeniden işlevlendirilmiş mekânlarda ise zaman zaman güncellemeler yapılarak yapının özgün kimliğini kaybetmeden korunması sağlanmalıdır.

Yeniden işlevlendirme yapıların korunması için bir gerekliliktir. Ancak yeniden işlevlendirme yapılırken yapıların kendine özgü özelliklerinin bozulmamasına dikkat etmek gerekmektedir. Yapıya ait özellikler, kullanıcı deneyimleriyle birleştiğinde yapının sosyal özelliklerinin de gelecek kuşaklara aktarılması sağlanacaktır. 


\section{KAYNAKÇA}

\section{Arşiv Kaynakları}

Antalya Vakıflar Bölge Müdürlüğ̈̈ (AVBM), 070001038-BN001 İlgi Yazısı.

Antalya Kültür Varlıklarını Koruma Bölge Kurulu Arşivi, Kültür Varlıklarını Koruma Envanteri (K.V.K.E).

Koruma Uygulama ve Denetim Büroları (KUDEB)

\section{Kaynak Eserler}

Akın C., Bekleyen A. \& Yıldırım M. (2016). "Preservation Initiatives for the Truncated Pyramid Shaped Traditional Houses of Siirt". Frontiers of Architectural Resarch 5/3 (2016) 360-370.

Burnyeat M. F. (1976). "Protagoras and Self-Refutation in Plato's Theaetetus". The Philosophical Review 85/2 (1976) 172-195.

Çeçen A. (1995). Insan hakları (Vol. 2). Ankara 1995.

Çelik Başok G. (2016). Conservation History of Cultural Heritage in Kaleiçi District in Antalya (From the $20^{\text {th }}$ Century to Present Day). Yayımlanmamış Doktora Tezi. Ortadoğu Teknik Üniversitesi, Ankara 2016.

Çimrin, H. (09.04.2018). Sabah Gazetesi. “Antalya Mevlevihanesi”. Kaynak: https://www.sabah.com.tr/ akdeniz/2018/04/09/antalya-mevlevihanesi. Erişim Tarihi: 11. Şubat 2020.

Deniz C. (2019, Nisan 15). Hürriyet Gazetesi. "Kaleiçi yaşayan müze oluyor". Kaynak: https://www.hurriyet.com.tr/yerel-haberler/antalya/kaleici-yasayan-muze-oluyor-41182960. Erişim Tarihi: 08. Şubat 2020.

Dewey J. (2012), Okul ve Toplum. Ankara 2012.

Eroğlu A. (2011). John Dewey'de Deneyim ve Sanat. Yayımlanmış Yüksek Lisans Tezi. Atatürk Üniversitesi, Erzurum 2011.

Evliya Çelebi. ( 2016) Günümüz Türkçesiyle Evliya Çelebi Seyahatnamesi 2/9. İstanbul 2016.

Genç B. (2009). Deneyimsel Pazarlamanın Tüketici Satın Alma Kararlarına Etkisi. Yayımlanmamış Yüksek Lisans Tezi, Ege Üniversitesi, İzmir 2009.

Gönül B. \& Yılmaz F. (2016). "Tarihi Yapılarda Yeniden Kullanımın İşlevsel Boyutu”. İçlis: İç Mimarlık Lisansüstü Çalışmalar Seтроzyuтu I. (16-17 Haziran 2016). ISBN:978 -975-561-472-4. (2016) 79-88.

Gül M. (2006). “Antalya Kent Merkezi Kültür ve Turizm Gelişim Bölgesinde Yer Alan Sit Alanları ve $\mathrm{Bu}$ Alanlarda Antalya Büyükşehir Belediyesince Başlatılan Çalışmalara İlişkin Genel Bir Değerlendirme". Planlama Dergisi 4 (2006) 121-145.

Güzel Ö. (2013). "Duyu Tabanlı Pozitif Yüklü Duygu ve Hislerin Satın Alma Sonrası Eğilimlere Etkisi: Alman Turistler Üzerinde Bir Araştırma". Anatolia: Turizm Araştırma Dergisi 24/2 (2013) 226-236.

Hulten B., Broweus N. \& van Dick M. (2009). Sensory Marketing. New York 2009.

Hunter Burkett M. \& Burdick A. (2019). "Adaptive Use of Small-Scale, Civic Infrastructural Heritage". Proceedings of the Institution of Civil Engineers - Engineering History and Heritage 172/3 (2019) 136-143. doi:10.1680/jenhh.18.00031.

Kaplan K. (2018). Turizm Faaliyetlerinin Şehirsel Gelişmeye Etkileri: Antalya Örneği. Yayımlanmış Doktora Tezi. İstanbul Üniversitesi, İstanbul 2018.

Keleş E. \& Çepni S. (2006). "Beyin ve Öğrenme”. Türk Fen Eğitim Dergisi 3/2 (2006) 66-82.

Kepenek E. (2011). Antalya Tarihi Kent Merkezi ve Yakın Çevresinin Mekân Dizim Metodu ile Analizi. Yayımlanmış Doktora Tezi. Süleyman Demirel Üniversitesi, Isparta 2011.

Kılıç S. (2015). Antalya'da Tek Kubbeli Cami ve Mescitler (Osmanlı Dönemi). Antalya 2015.

Kolb D. A., Boyatzis R. E. \& Mainemelis C. (2001). "Experiential Learning Theory: Previous Research And New Directions". Perspectives on Thinking, Learning, and Cognitive Styles 1/8 (2001) 227-247.

Numan İ. (1982). “Antalya Mevlevi Hânesinin Âsılı Hâli Hakkında Bâzı Düşünceler”. Vakıflar Dergisi XIV (1982) 125-137.

Önge Y. (1989). “Sinan’ın İnşa Ettiği Hamamları”. Vakıf Haftası Dergisi VI (1989) 255-272. 
Öymen Ö. N. \& Pulat G. G. (2009) "Bellek Ve Mekân İlişkisi Üzerine Bir Model Önerisi". İTÜ Dergisi 8/2 (2009) 145-155.

Pine B. J. \& Gilmore, J. H. (1999). İş Hayatı Bir Tiyatro. İstanbul 1999.

Schmitt B. H. (1999). "Experimental Marketing”. Journal of Marketing Management 15 (1999) 53-67.

Schmitt B. \& Simonson A. (1997). Marketing Aesthetics: The Strategic Management of Brands, Identitiy and Image. New York 1997.

Sönmez C. C. (2008). Antalya Kenti Kalesi'nin Tarihi: Burçlar, Kapılar ve Sur Duvarları. Antalya 2008.

van Boven L. \& Gilovich T. (2003). "To do or to Have? That is the Question". Journal of Personality and Social Psychology 85/6 (2003) 1193-1202.

Zoğal V. \& Emekli G. (2017). "Yaratıcı Turizme Kavramsal Ve Coğrafi Bir Yaklaşım”. Ege Coğrafya Dergisi 26/1 (2017) 21-34.

\section{Internet Kaynakları}

https://www.aa.com.tr/tr/turkiye/antalyada-762-yillik-mevlevihane-yeniden-hizmete-acildi/1168942\#, Şubat 2020.

https://www.kulturportali.gov.tr/turkiye/antalya/gezilecekyer/mevlevihane-muzesi, Şubat 2020.

https://tr.foursquare.com/v/cobalt-ceramic/4fe1b8316d86cb9bc26e533c, Şubat, 2020.

https://akmed.ku.edu.tr/kaleici-muzesi/aya-yorgi-kilisesi/, Mart 2020. 